\title{
Política on-line: a utilização do Twitter como ferramenta de capital social nas eleições presidenciais de 2010
}

\author{
Dejalma Cremonese \\ Doutor em Ciência Política (Universidade Federal do Rio Grande do Sul) \\ Professor na Universidade Federal de Santa Maria \\ dcremoisp@yahoo.com.br
}

\begin{abstract}
Resumo Este estudo guia-se pela hipótese de que a utilização das redes sociais (Twitter) nas eleições presidências de 2010 no Brasil foi um fator favorável à produção de capital social e civismo. Nesse sentido, este artigo apresenta um estudo sobre a utilização do Twitter pelos três principais candidatos à Presidência da República do Brasil nas eleições gerais de 2010: José Serra (PSDB), Dilma Rousseff (PT) e Marina Silva (PV). A presente análise acompanhou, mais especificamente, a conta do Twitter dos referidos candidatos por 120 dias (de 6 de julho até 2 de novembro de 2010). Utilizado pela primeira vez em um processo eleitoral no Brasil, o Twitter foi empregado principalmente para a divulgação das agendas, além de aproximar os eleitores de seus candidatos, catalisando participação cívica. Este trabalho procurou mostrar que o Twitter contribuiu para o debate democrático e para a mobilização do eleitorado dos referidos candidatos, principalmente os eleitores da candidata Marina Silva, o que levou a eleição a ser decidida em um segundo turno.
\end{abstract}

Palavras-chave: campanha eleitoral 2010, capital social, participação cívica, Twitter.

\section{Introdução}

E STE ARTigo TEM COMO OBjetivo estudar a utilização das redes sociais na campanha eleitoral de 2010, identificando as estratégias de atuação dos três principais candidatos à Presidência da República: José Serra (PSDB), Dilma Rousseff (PT) e Marina Silva (PV), no período do dia 6 de julho (início da campanha eleitoral) a 2 de novembro de 2010, dois dias após o encerramento do segundo turno (120 dias de análise). Especificamente, a pesquisa buscou acompanhar o emprego do Twitter como meio de divulgação das agendas, a evolução dos seguidores, a análise das mensagens postadas, a exposição na mídia eletrônica, bem como as estratégias de campanha dos referidos candidatos. $\mathrm{O}$ artigo questiona se a utilização do Twitter pelos candidatos foi um mecanismo de debate que ajudou a formar opinião e, consequentemente, traduziu em votos (serviu como um palanque eletrônico), ou foi apenas um mecanismo de propagação de ideias.

Sendo assim, pergunta-se: nas eleições presidenciais de 2010, a utilização do Twitter pelos candidatos contribuiu para conquistar o eleitorado, interferindo, assim, no resultado das eleições?

O artigo está estruturado em seis seções específicas. A primeira apresenta uma breve evolução histórica da internet no mundo, sua propagação no Brasil (evolução do número de usuários) e a importância 
do Twitter dentro das redes sociais. A segunda seção, após discorrer sobre o conceito de capital social, relaciona este com o Twitter, ao defendê-lo como ferramenta de participação cívica. A terceira traz a análise da utilização do Twitter na campanha eleitoral de 2010. Na quarta e quinta seções, respectivamente, é apresentada uma análise da utilização do Twitter pelos três principais candidatos à Presidência da República do Brasil, José Serra, Dilma Rousseff e Marina Silva, nos seguintes quesitos: evolução dos seguidores, postagem das mensagens, exposição e citação no Twitter, além das palavras mais citadas por eles. A sexta seção descreve aspectos relevantes da utilização do Twitter no segundo turno das eleições 2010. A pesquisa foi baseada na análise cotidiana das contas dos Twitters dos referidos candidatos na internet, além de utilizar dois sites que fazem a mensuração da evolução dos seguidores e das mensagens postadas: $<$ http://tweetstats.com $>$ e o $<$ http://twittercounter. $\mathrm{com} />$, respectivamente.

Considerando a participação política como uma das formas pelas quais o espaço on-line tem se mostrado importante para a análise de cientistas políticos, a questão proposta por este artigo é discutir a importância das redes sociais, principalmente o Twitter, na campanha eleitoral de 2010. A pretensão é demonstrar que o Twitter é um instrumento positivo, como espaço interativo, representando, assim, um novo modelo de esfera pública.

\section{A internet e as redes sociais}

De uso estritamente militar, a internet surgiu durante o período conhecido como Guerra Fria, logo após a $2^{a}$ Guerra Mundial, até fins dos anos 1980. Os Estados Unidos e a União das Repúblicas Socialistas Soviéticas (URSS), as duas maiores potências militares do planeta, confrontavam-se em uma guerra mais de cunho ideológico (informações) do que propriamente bélica, no intuito de defender e exaltar seus referidos sistemas políticos e econômicos, o capitalismo e o socialismo respectivamente. Os EUA, temerosos de serem atacados pelo inimigo, descentralizaram as informações, colocando-as em diferentes espaços geográficos, formando, assim, as redes de informações. Com o final da Guerra Fria, os EUA aprimoraram as pesquisas das redes de informação não mais de caráter militar, mas de cunho civil. Isto é, o aprimoramento técnico-científico dos norte-americanos levou a internet a se tornar a grande revolução da informação dos últimos tempos (Abreu).
O Brasil iniciou sua conexão com a rede mundial de computadores no final dos anos 1980 para uso estritamente acadêmico. Apenas as universidades tinham acesso à informação em rede. Com o passar do tempo, o uso deste meio foi se popularizando e, em 2005, segundo dados do IBGE, mais de 32 milhões de pessoas ( $21 \%$ da população brasileira) já haviam acessado a internet em algum lugar (domicílio, local de trabalho, estabelecimento de ensino, centro público de acesso gratuito ou pago) por intermédio de microcomputadores. Segundo a mesma pesquisa, mais da metade dos acessos foi feita por homens com idade entre 30 e 39 anos, com mais de dez anos de estudo e com rendimento em torno de mil reais mensais.

Dados mais atualizados demonstram que o Brasil alcança o número de 79,9 milhões de internautas, segundo o Ibope NetRatings. O Brasil é o quinto país mais conectado. De acordo com a Fecomércio$\mathrm{RJ} / \mathrm{Ipsos}$, o percentual de brasileiros conectados à internet aumentou de $27 \%$ para $48 \%$, entre 2007 e 2011 (http://goo.gl/8tBMn). ${ }^{1}$

Tabela 1 - Evolução da internet no Brasil (em milhões de usuários: 2005-2012)

\begin{tabular}{cc}
$\begin{array}{c}\text { Evolução de usuários da internet no Brasil em milhões } \\
\text { (ano - milhões) }\end{array}$ \\
2005 & 32 \\
2007 & 50 \\
2008 & 56 \\
2009 & 64 \\
2010 & 73 \\
2012 & 80 \\
\hline
\end{tabular}

Fonte: Elaborado pelo autor

Nos últimos tempos, houve um incremento de aproximadamente 7,6 milhões de novos usuários a cada ano, um acréscimo de $46 \%$ nos últimos três anos. Seguindo esse percentual de crescimento, chegaremos em 2020 com aproximadamente $149 \mathrm{mi}-$ lhões de usuários.

O desenvolvimento da internet incorporou ao jogo político novos fluxos e atores, criando novas correntes comunicacionais, que contribuem para a ampliação do debate político para além das esferas institucionais e dos meios de comunicação em massa, como é o caso do Twitter (O'Reilly, 2005, apud Teixeira, 2011, p. 8). A priori, o sistema mundial de computadores representa um caráter complementar, liberando o indivíduo da condição permanente de receptor passivo de informações. Assim, a criticidade comumente manifestada pela opinião pública em relação à política é um ponto útil de partida para a mu- 
tação do pensamento político (Coleman, 2003, apud Rothberg, 2011, p. 7).

Assim sendo, essa maior interatividade por meio da internet pode ser a representação de um engajamento cívico, da mesma forma que ler notícia e conversar com amigos sobre política. Neste sentido, tem sido apontado que a mutação de posicionamentos pela internet poderia adotar uma função relevante na criação de capital social, a qualidade derivada de relacionamentos sociais cooperativos que incitam o fortalecimento dos direitos de cidadania em coletividades que situam a participação popular como primazia nos processos democráticos de formulação, execução e fiscalização de políticas públicas (Rothberg, 2011, p. 11).

Além de demonstrar um possível engajamento cívico e, por consequência, um acréscimo de capital social, a participação on-line, através de seus debates virtuais, não pode ser menosprezada como indicador da vitalidade democrática, em contraposição à apatia política.

Em suma, estar desconectado, hoje, não é uma boa opção. É o que afirma Castells (2005, apud Teixeira, 2011, p. 11), o qual alerta para o fato de que as pessoas privadas do acesso à internet apresentam uma fragilidade cada vez mais perceptível pelas empresas empregadoras. Além disso, os territórios desconectados da internet perdem a capacidade de competitividade econômica internacional. Nessa mesma linha e sempre com um toque crítico, alertando para o risco de "marginalidade" e de "apartheid digital", Dupas (2005, apud Teixeira, 2011, p. 11) ressalta que a qualificação do trabalhador é cada vez mais importante numa economia que depende da habilidade de descobrir, processar e aplicar informações on-line.

Todo esse amplo processo de maior participação política através do novo âmbito público pôde ser observado nas eleições presidenciais em 2010, nas quais ferramentas como o Twitter tiveram importante participação na interação entre candidatos e eleitores.

Segundo Castells (2005, apud Teixeira, 2011, p. 9), o conceito de sociedade em rede se define por uma sociedade que tem sua estrutura baseada "em torno de redes de informação a partir da tecnologia da informação microeletrônica estruturada na internet". Uma vez inseridas neste modelo de sociedade, que abrange um grande número de indivíduos hoje, as redes sociais desempenham um papel importante, não apenas como meio de comunicação, mas também ampliando a esfera pública, através de interação e participação.

Em termos gerais, as redes sociais são relações estabelecidas entre indivíduos com interesses comuns em um mesmo ambiente. $\mathrm{Na}$ internet, as redes sociais são as comunidades on-line como Orkut, Facebook, MySpace e Twitter, em que internautas se comunicam, criam comunidades e compartilham informações e interesses semelhantes. ${ }^{2}$

Entre as principais redes sociais do país, as mais acessadas foram o Facebook e o Twitter. Segundo estudo publicado no mês de outubro de 2010 pela ComScore, empresa de marketing digital, 23\% dos usuários de internet no Brasil - em comparação com os $11,9 \%$ dos EUA - visitaram o Twitter em agosto daquele ano, a mais alta taxa de participação no mundo. ${ }^{3}$ O Facebook teve aumentado seu acesso em $804 \%$ desde abril de 2009 , e o Twitter cresceu $768 \%$. O Orkut, que até pouco tempo era a rede social mais acessada no Brasil, perdeu espaço para o Facebook. ${ }^{4}$ Os sites mais visitados no Brasil são os mecanismos de buscas (como o Google), com 20,7\%, seguidos pelas redes sociais, com $15,1 \% .^{5}$

Interessa para este estudo uma análise sobre o Twitter, que é um microblog criado em 2006 por Jack Dorsey, que permite aos usuários cadastrados emitirem pequenas mensagens de texto (até $140 \mathrm{ca}-$ racteres) por meio da própria web ou ainda por SMS ou e-mail. As atualizações (chamadas de tweets) são exibidas em tempo real na página do perfil do usuário e enviadas automaticamente a todos os que o seguem (followers). Os dispositivos de interação incluem a resposta $($ reply) ou a republicação (retweet) da mensagem original. O usuário pode seguir (following) ou ser seguido (ter followers) por uma infinidade de usuários, não necessariamente conhecidos e próximos do interlocutor, unidos por interesses e ideias comuns. ${ }^{6}$

No mundo são mais de 105 milhões de usuários do Twitter. O Brasil já é o segundo país em número de tuiteiros, com mais de 10 milhões de contas. A cada minuto pipocam 36 mil tweets no planeta. A desigualdade, porém, é alta nesta nação: 5\% dos usuários são responsáveis por $75 \%$ dos tweets. A grande maioria não posta nada, nunca. ${ }^{7}$ Ainda, segundo a mesma

2. O que é: rede social. 2008. Disponível em: <http://g1.globo.com/Noticias/0,,MUL394839-15524,00.html>. Acesso em: 27 ago. 2010.

3. Por que o Twitter é tão popular no Brasil? 2010. Disponível em: <http://www.ihu.unisinos.br/index.php?option=com_noticias\&ltemid=18\&t ask=detalhe\&id=37771>. Acesso em: 27 nov. 2010.

4. Em 2012, o Facebook passou a ser a rede social mais usada no Brasil. Informação disponível em: http://www.tecmundo.com.br/ facebook/19481-e-oficial-facebook-e-a-rede-social-mais-utilizada-no-brasil.htm. Acesso em: maio 2012.

5. Facebook e Twitter crescem nas redes sociais; Orkut continua líder. 2010. Disponível em: <http://www1.folha.uol.com.br/folha/informatica/ ult124u726772.shtml>. Acesso em: 27 ago. 2010.

6. Conferir o trabalho de Ramaldes (2009).

7. República do Twitter. Revista Superinteressante. 2010. Disponível em: <http://super.abril.com.br/alimentacao/republica-twitter-544297. shtml>. Acesso em: 28 ago. 2010. 
fonte, os usuários do Twitter postam 50 milhões de mensagens por dia (600 tweets por segundo). As pessoas postam (conforme o Gráfico 2 a seguir), mais questões pessoais de pouco interesse ("Baboseira") $40,5 \%$. Por outro lado, temos 37,5\% de usuários que utilizam o Twitter para postar opiniões e conversas.

Gráfico 2 - O que as pessoas tuítam

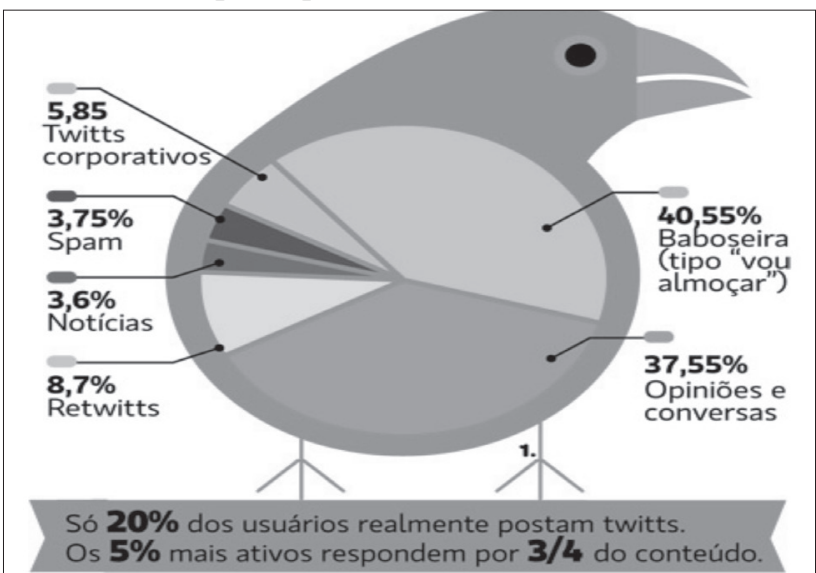

Fonte: Revista Superinteressante, 2010.

Segundo o censo de usuário do Twitter no Brasil, a grande maioria tem este instrumento para uso pessoal (97,5\%), enquanto apenas $2,5 \%$ empregam o Twitter para divulgar suas empresas. ${ }^{8}$

No quesito gênero, os homens estão à frente na utilização do Twitter: são 55,7\% contra 42,4\% das mulheres, enquanto as empresas representam 1,8\%. No quesito faixa etária, percebe-se que as pessoas que têm entre 19 e 24 anos são a maioria, com 43,8\%, seguidas pela população de faixa etária dos 15 aos 18 anos e pelos usuários que têm entre 31 e 35 anos.

Por fim, o censo informa que o estado de São Paulo tem o maior percentual de internautas que acessam o Twitter (43,5\%), seguido pelo estado do Rio de Janeiro, com 13,5\% e, em terceiro, Minas Gerais, com 10,1\%. A maioria acessa somente em casa $(35,8 \%)$ e em casa e no trabalho (33\%). Dos internautas, $66,7 \%$ usam o navegador para tuitar e $16,7 \%$, o navegador e o celular.

\section{A política on-line como geradora de capital social}

Partindo da premissa de que o uso das redes sociais possa contribuir para a geração de capital social, esta seção apresenta uma definição para tal conceito sob a perspectiva do cientista político Robert Putnam (2002). Logo após pretende-se apontar sua relação com a participação política on-line.

Apesar de sua repercussão entre cientistas sociais, há certa dificuldade para definir esse conceito, pois não existe um consenso entre seus teóricos, no momento em que há vários entendimentos sobre o que ele constitui. Sendo assim, ele não é homogêneo e ainda está sendo desenvolvido.

O conceito de capital social é relativamente recente, sendo perceptível de forma implícita, pela primeira vez em 1835 na obra Democracia na América, de Tocqueville. Esse autor, mesmo sem ter usado o referido termo, deixou-o presente ao falar da comunidade cívica que tornava peculiar os Estados Unidos. Após a indicação tocquevilleana, o conceito foi inaugurado por Hanifan no início do século XX, com o artigo "The rural school community center" (1916), que definiu-o como a unidade social que resulta das relações entre indivíduos e famílias. Posterior a Hanifan, em 1961, a urbanista Jane Jacobs utilizou o termo para referir-se às redes sociais que são insubstituíveis à vida das cidades. Assim, procedendo ao resgate do termo por Jacobs, diversos autores passaram a fazer uso desse conceito. Seus teóricos mais reconhecidos na academia são Pierre Bourdieu, James Coleman, Francis Fukuyama e Robert Putnam. ${ }^{9}$

Putnam, através de um estudo de mais de vinte anos sobre a Itália, que resultou no livro Comunidade e democracia: a experiência da Itália moderna (Putnam, 2002), analisa as diferenças de desempenhos das regiões italianas, buscando as origens de um governo eficaz, alicerçado nas tradições cívicas, na comunidade, na democracia, no capital social e nos contextos históricos e econômicos de cada região italiana. Com esse trabalho, o autor popularizou o conceito na Ciência Política, ao defender que o capital social diz respeito "a características da organização social, como confiança, normas e sistemas, que contribuam para aumentar a eficiência da sociedade facilitando as ações coordenadas" (Putnam, 2002, p. 177).

Em tal obra, Putnam destaca a história da Itália: até 1970 esse país tinha sua administração centralizada em Roma, sendo que nesse ano ela foi regionalizada. Os vinte governos regionais tinham estruturas e recursos basicamente idênticos, porém seus desempenhos eram assimétricos. De tal modo, constatando as diferenças de desempenho nos governos regionais italianos, Putnam buscou identificar quais fatores catalisam essas assimetrias Nesse sentido, o autor percebeu que o fator "desempenho institucional" estava diretamente relacionado com o "desenvolvimento

8. Censo de usuários de Twitter no Brasil. 2010. Disponível em: <http://www.twittercentral.com.br/censobr/>. Acesso em: 28 ago. 2010.

9. Destacando que as perspectivas desses autores divergem em alguns pontos, pois, além de visões, adotam metodologias e objetos diferentes. A que será apresentada aqui é a de Robert Putnam. 
econômico" de cada região. No entanto, ele alerta para o fato de que, por trás dessa relação, possa existir outros fatores condicionando o desenvolvimento econômico. Um é o contexto histórico de cada região e o outro, mais valorizado pelo autor, é a comunidade cívica presente nas regiões italianas. Assim, partindo da definição tocquevilleana de comunidade cívica, Putnam afirma que esta "se caracteriza por cidadãos atuantes e imbuídos de espírito público, por relações políticas igualitárias, por uma estrutura social firmada na confiança e na colaboração" (2002, p. 30-31).

Para identificar as regiões que mais apresentam comunidade cívica, Putnam definiu quatro indicadores do civismo: voto preferencial; comparecimento a referendos; quantidade de associações desportivas e culturais, e leitura de jornais. Nesse contexto, o autor conclui que "as regiões onde é maciço o comparecimento às urnas nos referendos e inexpressivo o uso do voto preferencial são praticamente as mesmas onde existem uma densa rede de associações civis e um elevado número de leitores de jornais" (Putnam, 2002, p. 110). Desse modo, dando evidência ao indicador que se refere à quantidade de leitores de jornais, destaca-se que, com a modernização dos meios de comunicação, os jornais não são mais os únicos meios de levar informação aos eleitores. Assim como Putnam identificou no número de leitores de jornais o interesse dos cidadãos pelos assuntos comunitários, com o advento das novas tecnologias podemos identificar a utilização de ferramentas como o Twitter como reflexo dessa característica.

Como seguidor de Tocqueville, Putnam baseiase nele para relacionar a vitalidade cívica com os periódicos locais, uma vez que, para ele, "uma associação democrática dificilmente pode prescindir de um jornal" (Tocqueville, apud Putnam, 2002, p. 106). Assim, contemporaneamente, poderíamos dizer que a participação cívica não prescinde da utilização de redes sociais como o Twitter, uma vez que, através dessa ferramenta, o eleitor pode acompanhar a vida política dos candidatos e, por consequência, votar de forma mais consciente.

Portanto, defendendo que a utilização do Twitter - que aproxima o candidato do eleitor ao informá-lo de sua agenda política - é um fator responsável pela produção de capital social e civismo em uma sociedade, define-se, por consequência, que este também resulta em governos mais democráticos. Desse modo, esta teoria é fomentada pela de Putnam, quando este afirma que "as regiões onde há muitas associações cívicas, muitos leitores de jornais, muitos eleitores politizados e menos clientelismo parecem contar com governos mais eficientes" (2002, p. 113). No contexto histórico e geográfico em que o autor analisou a participação cívica e o índice de capital social, a ferramenta que era mais utilizada pelos cidadãos era a mídia impressa; hoje, no contexto que se analisa aqui, a ferramenta de informação ao eleitor que vem ganhando espaço é o Twitter.

Destaca-se a relevância das redes sociais, principalmente da apresentada aqui, para a produção de capital social, pelo fato de elas não serem apenas um meio de informação ao cidadão, mas também uma possibilidade de interação com os candidatos e com os demais eleitores. O Twitter permite ao usuário, além de acessar o que os candidatos escrevem, que ele também interaja com os demais eleitores que fazem uso dessa ferramenta. Além disso, o Twitter é fonte de civismo no momento em que possibilita ao eleitor levar suas demandas e opiniões ao acesso do candidato.

Putnam defende que, em uma região cívica, quando os cidadãos se encontram na rua, provavelmente já leram o jornal daquele dia e o debatem, o que é diferente em uma região menos cívica. Nesse sentido, no contexto em que se está trabalhando, pode-se dizer que hoje não é mais necessário se encontrar na rua para discutir política, pois as novas tecnologias possibilitam esse encontro por meio de redes sociais. Desse modo, podemos "pensar no ciberespaço como uma nova esfera pública de conversação onde o 'mundo da vida' amplia o capital social, recriando formas comunitárias, identitárias (público), ampliando a participação política" (Lemos, 2009, p. 27).

Assim sendo, através de meios de comunicação tradicionais, como o jornal, ou então modernos como o Twitter, os eleitores que fazem uso dessas ferramentas são mais informados do que os demais e "portanto têm mais condições de participar das deliberações cívicas" (Putnam, 2002, p. 106). Dessa forma, vai-se analisar na seção seguinte como os principais candidatos às eleições presidenciais de 2010 no Brasil Dilma Rousseff, José Serra e Marina Silva - fizeram uso dessa importante ferramenta para mobilizar seus eleitores, apresentar seus programas de governo e publicizar suas agendas.

\section{A utilização do Twitter na campanha eleitoral de 2010}

Com a Resolução $\mathrm{n}^{\circ}$ 12.034, de setembro de 2009, referente ao uso da internet nas eleições, passa ser permitida a propaganda por meio de blogs, redes sociais e sítios de mensagens instantâneas, cujo conteúdo pode ser elaborado por candidatos, partidos, coligações ou por iniciativa de qualquer pessoa natural, o que vai além do que previa a resolução que abrangeu o pleito de 2008, que dizia que a propaganda eleitoral só era permitida na página do candidato destinada exclusivamente a esse fim. Assim, este fato, 
agregado ao fortalecimento do Twitter como rede social, inovou a política brasileira nas últimas eleições.

O Twitter foi adotado por boa parte dos políticos brasileiros. O Twiticos (@twiticos),especializado justamente em seguir os perfis ligados a políticos e a partidos, certificando sua autenticidade, tinha em suas listas mais de 900 políticos cadastrados. Eram 271 deputados federais, 207 perfis ligados a partidos, 131 vereadores, 111 deputados estaduais, 56 senadores, 11 ministros e 6 governadores. ${ }^{10}$

Lopes, em seu artigo "Política na rede", fala que o cidadão comum vê esse tipo de informação como uma ferramenta importante de participação política nas democracias contemporâneas. Para ela, os veículos de informação ampliam o horizonte de informação disponível aos cidadãos. Em suma, "o consumo e principalmente a procura ativa pela informação disponível nos meios de comunicação de massa têm relação positiva com uma cidadania mais próxima e otimista em relação à esfera pública" (Lopes, apud Aldé, 2004, p. 202).

A internet hoje é um meio de comunicação relevante para a formação de opinião pública e é também uma forma de manifestar essas opiniões. De acordo com Lévy (2000), a internet pode ser um meio no qual os indivíduos podem explorar suas potencialidades através das comunidades virtuais e onde se reúnem pessoas com afinidades para compartilharem tanto assuntos "sérios" quanto assuntos "fúteis" (Lévy, 2000, p. 132). É criado um espaço em que cada um, onde estiver, pode exprimir suas ideias, por mais singulares que possam ser. A internet mudou a forma como as pessoas consomem conteúdos informativos, ao mesmo tempo em que passou, também, a produzi-los e distribuí-los em escala mundial numa velocidade jamais vista.

A prática de trocar mensagens, anunciar uma entrevista coletiva, uma viagem de campanha (agenda do candidato), ou simplesmente pedir votos através da internet, não é propriamente nova no meio político. Ela se tornou popularmente conhecida na última eleição presidencial norte-americana, quando o então candidato Barack Obama utilizou redes de relacionamento como o Twitter, Facebook e o YouTube para se comunicar e interagir com os eleitores. Por outro lado, a receptividade e a aceitabilidade dessa nova forma de fazer política foram enormes, na medida em que, segundo o estudo do instituto Pew Internet \& American Life Projec, três em cada quatro internautas americanos usaram a web para ler notícias e se informar sobre a campanha política de $2008 .{ }^{11}$
No Brasil, os três principais candidatos à Presidência da República em 2010 (Dilma Rousseff, José Serra e Marina Silva) utilizaram com frequência o Twittercom suas respectivas contas@dilmabr,@joseserra_e@silva_marina.

Estudos da empresa E.Life, especializada em gestão do relacionamento em mídias sociais, revela que, em uma semana (de 25 a 31 de maio de 2010), as mensagens emitidas pelo microblog Twitter sobre os candidatos à presidência atingiram potencialmente até 5 milhões de usuários. Segundo o levantamento, os posts sobre Dilma Rousseff (PT) atingiram quase 1.747.000 tuiteiros no período avaliado. Mensagens em que o assunto era José Serra (PSDB) impactaram 1.580.000 usuários, enquanto aqueles sobre Marina Silva (PV) chegaram a 1.630.000. Com toda essa abrangência de audiência, o Twitter passou a ser um bom instrumento de proselitismo político através de mensagens diretas a todos os seus respectivos seguidores.

A partir da próxima seção, apresentamos mais objetivamente a utilização do Twitter pelos três candidatos mencionados a partir da visibilidade na imprensa on-line, como candidatos mais comentados, as menções no Twitter e a citação em diferentes meios de comunicação do país no primeiro turno das eleições 2010.

\section{A visibilidade e citações dos candidatos no primeiro turno}

A partir da análise do Gráfico 6, percebe-se que o grau de visibilidade na imprensa on-line e no Twitter de José Serra e Dilma Rousseff (de 2 de julho até o dia 31 de agosto) é quase idêntico. Já o grau de visibilidade da candidata Marina Silva foi um pouco inferior.

No quesito mais comentado (referências em notícias), porém, a candidata Dilma apareceu com maior frequência entre os dias 24 e 31 de agosto de 2010: foram 2.313 notícias. Serra foi o segundo mais mencionado, com 1.984 notícias, e, por fim, Marina Silva, com 780 notícias (Gráfico 7).

A candidata Dilma Rousseff apareceu igualmente na frente nas menções do Twitter. Foram 166.151 referências contra 67.104 de José Serra (Gráfico 8).

A partir de estudos do Observatório das Eleições 2010, foi possível visualizar quantas vezes um candi-

10. Números apresentados até a data da pesquisa: 26 de julho de 2010. Disponível em: <http://www1.folha.uol.com.br/folha/informatica/ ult124u683533.shtml>. Acesso em: 26 jul. 2010.

11. Ainda hoje o presidente Barack Obama utiliza com frequência o Twitter com a conta @BarackObama. O atual presidente dos EUA aproximase de 6 milhões de seguidores (são exatamente 5.974 seguidores, números do dia 27 de novembro de 2010). 
Gráfico 6 - Visibilidade dos candidatos na imprensa on-line (meses de julho e agosto)

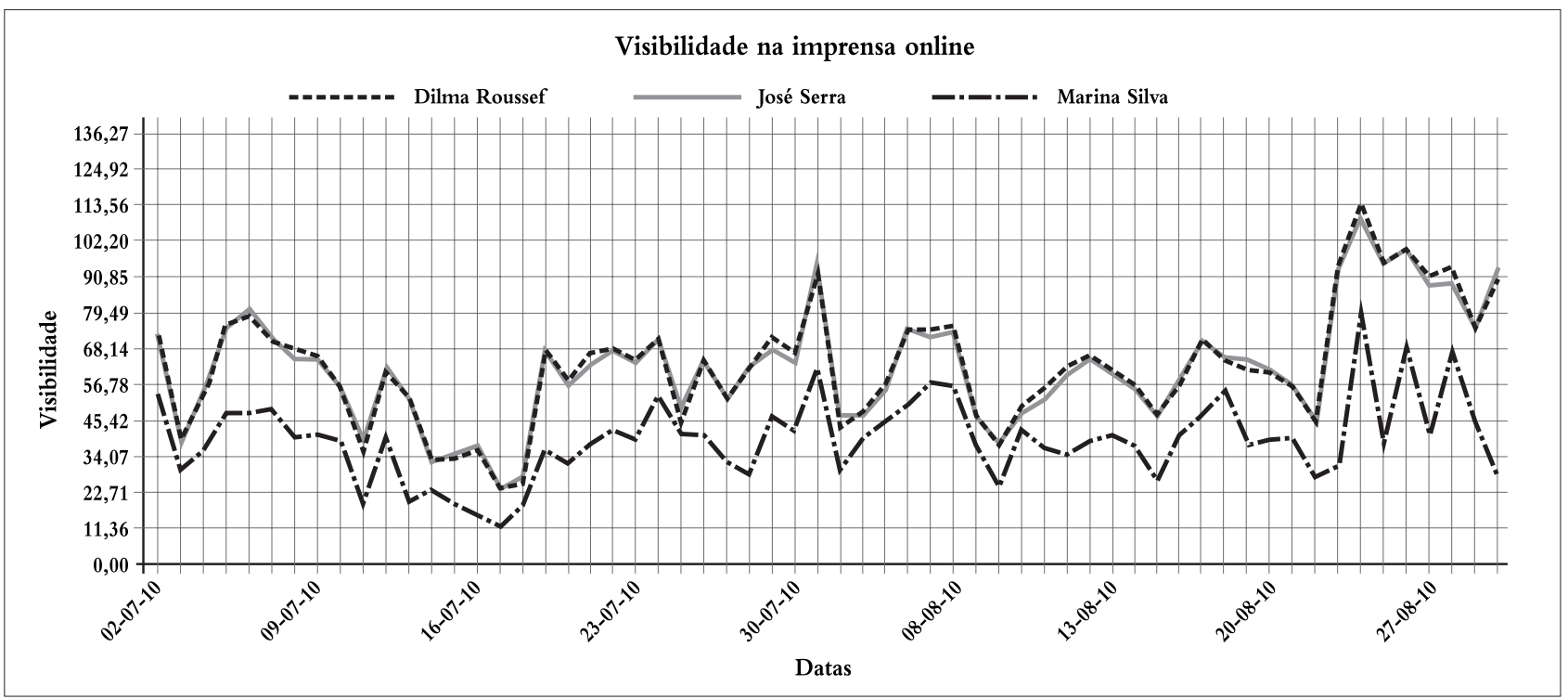

Fonte: Observatório das Eleições.2010. Disponível em: <http://www.observatorio.inweb.org.br/eleicoes2010/personalidades/dilma-rousseff>. Acesso em: 28 set. 2010.

Gráfico 7 - Candidatos segundo as referências em notícias (semana de $24 / 8$ a $31 / 8$ de 2010)

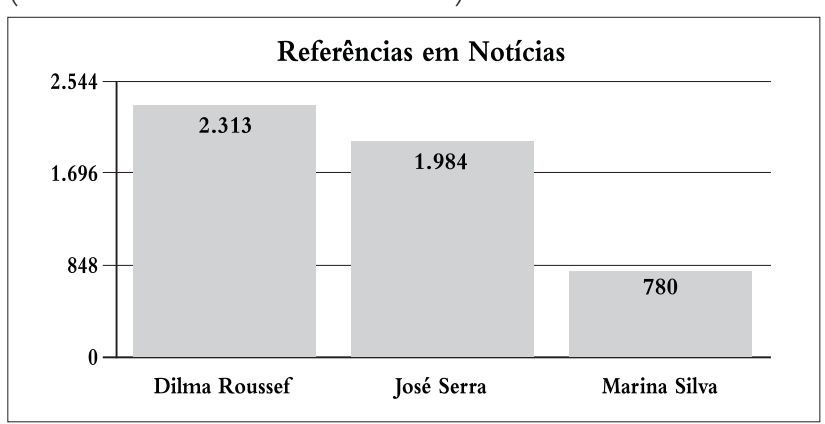

Fonte: Observatórios das Eleições. 2010. Disponível em: <http://observatorio.inweb.org.br/eleicoes2010/analises/visibilidade>. Acesso em: 28 Set. 2010 .

Gráfico 8 - Candidatos segundo as referências no Twitter (semana de $24 / 8$ a $31 / 8$ de 2010)

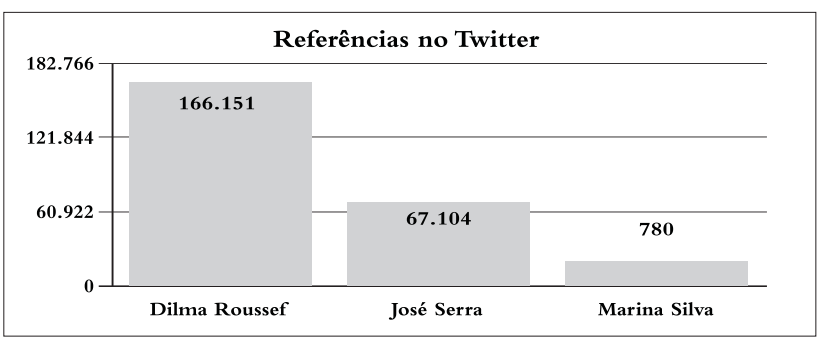

Fonte: Observatório das Eleições. 2010. Disponível em: <http://www. observatorio.inweb.org.br/eleicoes2010/destaques/>. Acesso em: 28 Set. 2010. dato foi citado por diferentes meios de comunicação do Brasil. ${ }^{12}$ No exemplo da Figura 1, visualizam-se as citações dos três principais candidatos à presidência em um dos jornais de maior circulação do Rio Grande do Sul, o Zero Hora (ZH), de Porto Alegre. O jornal $Z H$ citou 636 vezes o nome do candidato José Serra nos meses de julho e agosto de 2010, contra apenas 382 vezes o de Dilma Rousseff. Marina foi citada 200 vezes. Deixando a imparcialidade de lado, o referido jornal optou por privilegiar, divulgar e citar o candidato da oposição José Serra bem mais que a candidata da situação, Dilma Rousseff.

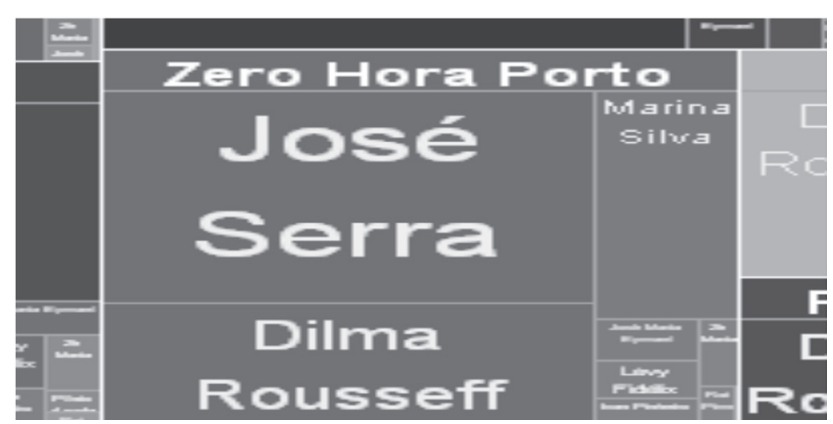

Figura 1 - Citação dos candidatos pelo jornal Zero Hora, de Porto Alegre

Fonte: Observatório das Eleições. 2010. Disponível em: <http://www. observatorio.inweb.org.br/eleicoes2010/fontes/treemap>.Acesso em: 29 Set. 2010 .

\footnotetext{
12. O Observatório das Eleições 2010 é um dos projetos de pesquisa do Observatório da Web, desenvolvido pelo InWeb - Instituto Nacional de Ciência e Tecnologia para a Web (<http://www.inweb.org.br/>). Com o objetivo de entender, em tempo real, o que está sendo veiculado nas várias mídias e pelos vários usuários, o portal utiliza dezenas de softwares e ferramentas inéditas de captura e análise de dados baseadas em código livre ou aberto. Os dados obtidos pelo Observatório das Eleições 2010 ajudam a traçar um panorama do cenário eleitoral do ponto de vista das informações e das opiniões que circulam na Web. As análises, no entanto, não refletem intenção de voto. A equipe de pesquisadores é coordenada pelo Departamento de Ciência da Computação da Universidade Federal de Minas Gerais (UFMG), em parceria com o Centro Federal de Educação Tecnológica de Minas Gerais (Cefet-MG), a Universidade Federal do Amazonas (Ufam) e a Universidade Federal do Rio Grande do Sul (UFRGS).
} 


\section{A evolução dos seguidores e das postagens das mensagens dos candidatos}

No quesito "seguidores", José Serra, por iniciar um ano antes sua conta no Twitter, apareceu com o maior número de seguidores. Logo após aparecia a candidata petista Dilma Rousseff em segundo lugar e, em terceiro, a candidata do PV, Marina Silva. No entanto, nos últimos dias da campanha eleitoral, véspera das eleições em primeiro turno, os simpatizantes e eleitores da candidata Marina se mobilizaram, vindo a ultrapassar a candidata petista.

Como demonstra o gráfico a seguir, após o dia 26 de agosto de 2010, os presidenciáveis (José Serra, Dilma Rousseff e Marina Silva) mantinham as referidas posições já citadas. Porém, no dia 27 de setembro, as posições se inverteram, com a candidata Marina ficando em segundo lugar no quesito "seguidores" até o dia da coleta dos dados (26 de novembro de 2010). Observe o Gráfico 9.

Já no quesito mensagem, a candidata Marina Silva foi quem mais postou. Como demonstra o Gráfico 10, em comparação aos demais candidatos, Marina Silva ficou em primeiro lugar; em segundo ficou José Serra e, em terceiro, Dilma Rousseff.

As mensagens dos candidatos geralmente dividiam-se em comunicações de divulgação ou de relacionamento. Comunicação de divulgação é quando o político posta mensagens mais formais, anúncios da agenda política - geralmente utiliza a terceira pessoa e é mais impessoal. Já as mensagens de relacionamento são mais informais, quando o candidato fala de sua vida pessoal e emprega a primeira pessoa. Dilma e Marina Silva postaram mensagens mais de divulgação

Gráfico 9 - Evolução dos seguidores no Twitter - por candidato

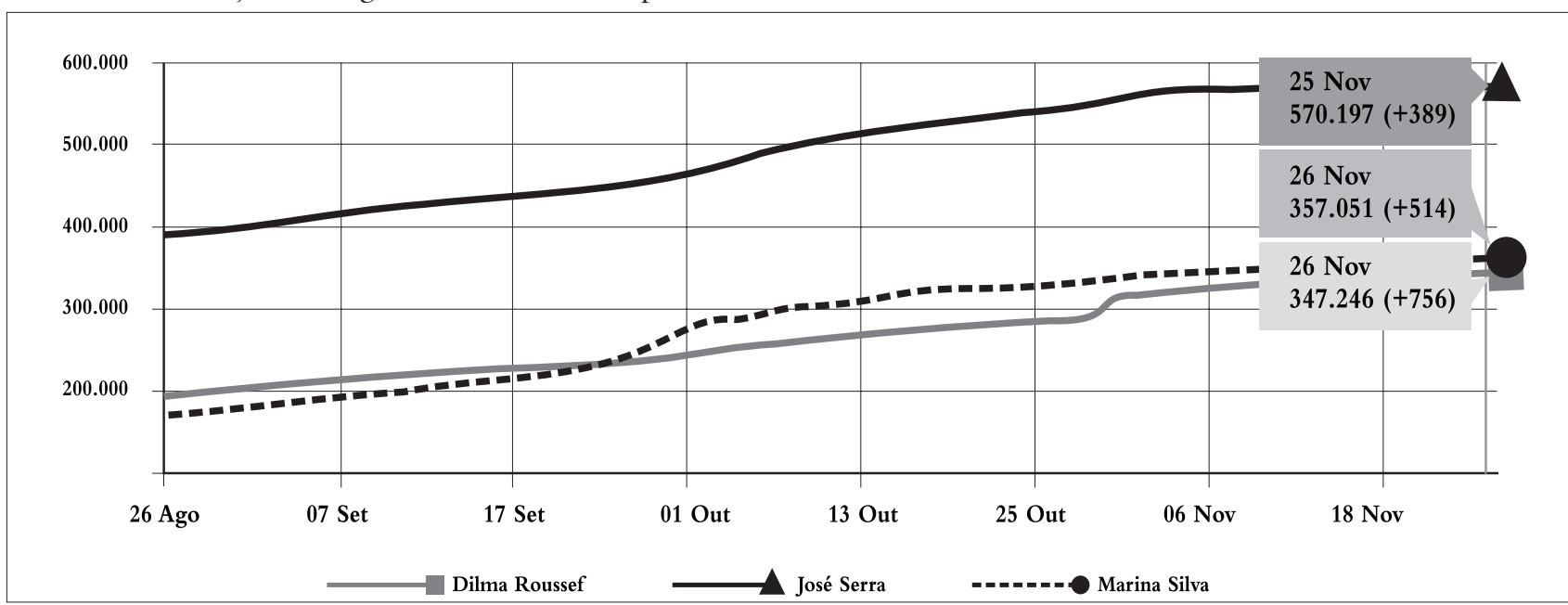

Fonte: Twitter Counter. 2010. Disponível em: <http://twittercounter.com/compare/joseserra_/dilmabr/silva_marina/all/followers>. Acesso em: 29 Set. 2010. José Serra twitter statistics.

Gráfico 10 - Número de mensagens postadas pelos candidatos durante o mês de agosto

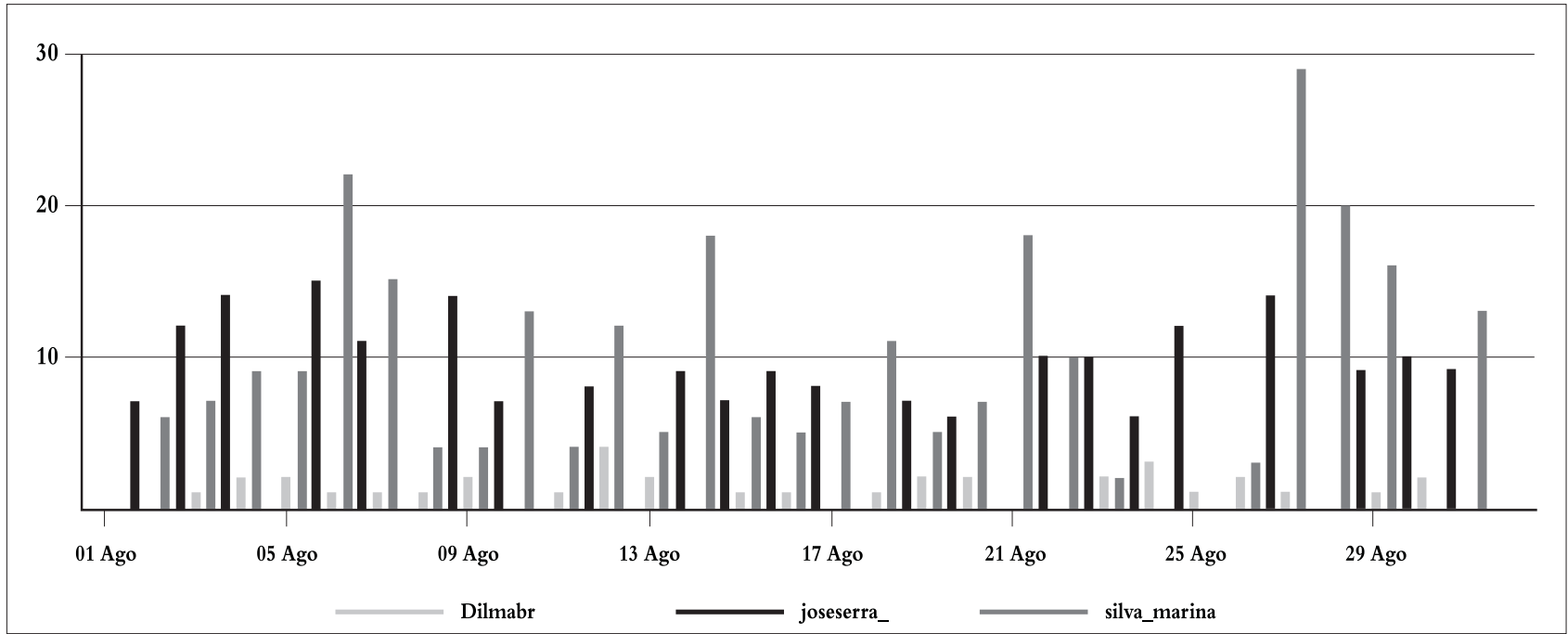

Fonte:Twitter Counter. 2010. Disponível em:<http://twittercounter.com/compare/joseserra_/dilmabr/silva_marina/month/updates>.Acesso em: 29 Set. 2010 . 
(formal) do que de relacionamento (pessoal) e José Serra postou mensagens mais de cunho de relacionamento (pessoal) do que de divulgação (formal).

\subsection{José Serra (@joseserra)}

Dos três candidatos em análise, José Serra foi o precursor na utilização do Twitter. Ele usa o instrumento desde 24 de abril de 2009. José Serra, do PSDB, foi o candidato que apareceu com o maior número de seguidores até a data do fechamento desta análise. ${ }^{13}$ Partiu de 282.407 seguidores no dia 6 de julho e, no final do mês de julho, dia 31, contava com 315.079 seguidores. Em 31 de agosto chegou a 395.508. No final da data de análise, dia 2 de novembro, José Serra ultrapassou os 560 mil seguidores. Foram 278.388 novos seguidores, em 120 dias de análise (um crescimento de 98,5\%), uma média de 2.319 novos seguidores por dia.

No quesito mensagens, o candidato do PSDB, do dia 6 de julho até 2 de novembro (120 dias), postou 395 mensagens, uma média de 6,9 mensagens por dia.

Gráfico 11 - Evolução dos seguidores de Serra (6 de ju1ho-2 de novembro)

\section{Evolução dos seguidores do candidato José Serra}

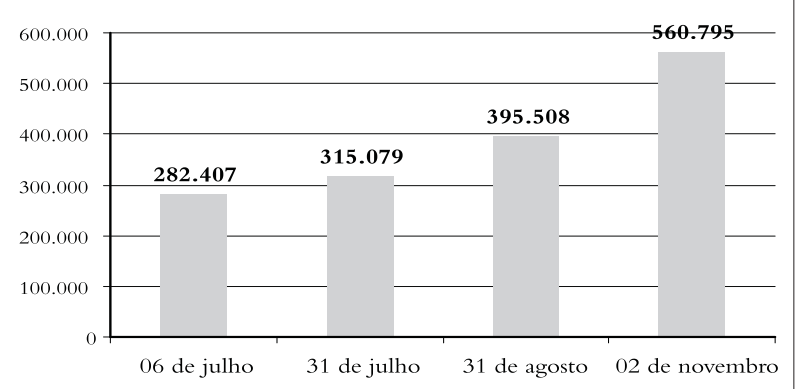

Fonte: Elaborado pelo autor, 2010

Sobre a experiência da utilização da internet, José Serra a achou muito positiva, principalmente do Twitter: "Foi bom participar do debate Folha/UOL. A internet é um instrumento poderoso. Eu aprendi muito nesses últimos anos, inclusive aqui no Twitter." O candidato afirmou que, muito antes do período eleitoral, já usava o Twitter: "Viu como sou eu mesmo, @Cleo_Oliveira? Estou no Twitter desde muito antes da campanha. Gosto daqui. Abs." E mais: "Essa pra mim é uma experiência única, extraordinária. E olha que eu já tive experiência na vida”, confirmou.

\section{As palavras mais usadas}

Desde o início da participação no Twitter, Serra postou 2.934 mensagens. Destas, a palavra mais citada foi "migre" (890 menções). Isto é, 1/3 das mensagens indicava ao seguidor o acesso a um link, um vídeo ou fotos da campanha do candidato. Mencionou a palavra "São Paulo" 280 vezes contra 124 vezes a palavra "Brasil". A palavra "eu" foi mencionada 199 vezes nas mensagens, contra apenas 48 repetições da palavra "nós"; "minha" apareceu 139 vezes contra 45 vezes da palavra "nossa". Como Serra posta as mensagens de madrugada, a palavra "dormir" foi mencionada muitas vezes.

Serra tinha um horário peculiar para se comunicar com seu público. $\mathrm{O}$ candidato tuitava da meia-noite às 4 da madrugada. Nas suas palavras: "Sou veterano, mas hoje passei do horário... rs Boa noite a todos" (a hora da mensagem denunciava: 3:17 AM Jul 14th via web). José Serra retuitou (RT) em 14,02\% das suas mensagens. RT significa retweet, quando o candidato apenas reenvia uma mensagem já postada por outro seguidor.

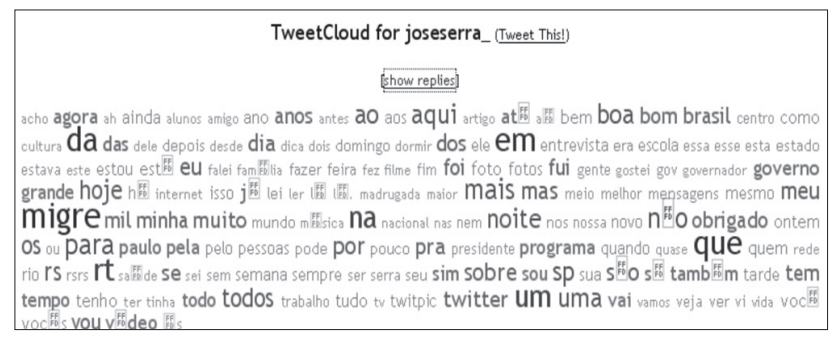

Figura 2 - Palavras mais citadas por José Serra no Twitter Fonte: Tweerstats. 2011. Disponível em: < http://tweetstats.com/graphs/ joseserra_\#tcloud>.Acesso em: 3 Nov. 2010.

A partir da Figura 2, percebe-se que Serra utilizou o Twitter para demonstrar-se um candidato bem mais descontraído do que parece na realidade, bem menos formal do que parece no dia a dia, falando de amigos, cultura, escola, filmes, música.

\subsection{Dilma Rousseff (@dilmabr)}

A candidata Dilma Rousseff começou a acessar o Twitter bem mais tarde do que o candidato José Serra. Foi no dia 10 de abril de 2010. Dilma assim se expressou sobre a utilização do Twitter: "Bom dia, boa tarde, boa noite $\mathrm{p} /$ quem me lê em qualquer lugar do mundo. Começo hoje minha aventura no Twitter. Quero aprender c/ vcs."

Dilma foi, no período estudado, a terceira colocada no quesito "seguidores no Twitter". No dia 6 de julho, ela contava com 105.101 seguidores, passou para 133.278 no dia 31 de julho e, em 31 de agosto, contava com 196.903 seguidores. Já no final da análise, no dia 2 de novembro de 2010 , contava com 311.879 seguidores. Um crescimento de 206.778 novos seguidores (196,7\% de crescimento no período). Por dia, a média de crescimento de novos seguidores foi de 1.723 . 
Gráfico 12 - Evolução dos seguidores de Dilma Rousseff (6 de julho-2 de novembro)

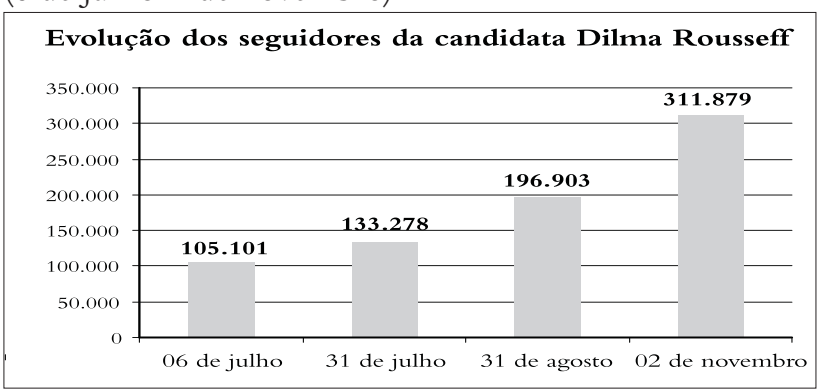

Fonte: Elaborado pelo autor 2010

No quesito postagem de mensagem, Dilma foi quem menos postou. Nos 120 dias pesquisados, foram apenas 85 mensagens, uma média de 1,4 por dia. Ela vinha com uma média de 57 mensagens por mês $(2,8$ por dia) antes de começar o horário eleitoral gratuito (dia 6 de julho). Dilma postou as mensagens com maior frequência no final do turno da tarde, entre 17 e 20 horas. De suas mensagens, $12 \%$ foram enviadas por seus seguidores; a candidata deu RT.

\section{As palauras mais citadas}

Desde o início da utilização do Twitter, Dilma postou, em comparação com Serra, um número bem menor de mensagens, apenas 296. Destas, a palavra mais citada foi "Brasil" (25 vezes): "Recarregando baterias p/a semana. Percorrer o Brasil tem sido muito gratificante. Mas na hora que o Gabriel chegar, largo tudo e vou para lá." Mencionou ainda, com bastante frequência, a palavra "pessoal" (25 vezes): "Pessoal, muito obrigada pelas mensagens. Achei o debate da Band bom, muito útil $\mathrm{p} / \mathrm{o}$ eleitor nos conhecer melhor." A palavra "obrigada" foi citada 23 vezes: "Chegamos às 4hs da manhã de Garanhuns, mas valeu. Obrigada, pessoal, pela acolhida e pela linda festa!

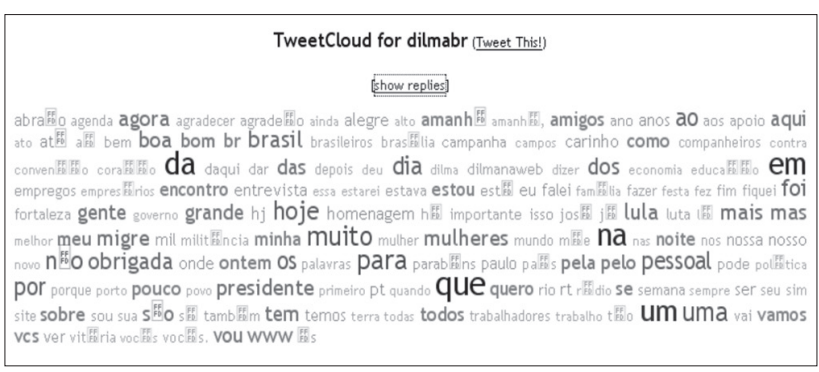

Figura 3 - Palavras mais citadas por Dilma Rousseff no Twitter

Fonte: Tweetstats. 2010 Disponível em: <http://tweetstats.com/graphs/ dilmabr\#tcloud_words>.Acesso em: 3 Nov. 2010

Dilma mencionou, ainda, "presidente Lula" 19 vezes: "Agora, dormir cedo porque amanhã tem panfletagem na porta da fábrica da Mercedes em S. Ber- nardo. Depois, café c/presidente Lula e o pessoal." Por sua vez, a palavra "Mulheres" apareceu 19 vezes: "Chegando a Brasília, depois de uma conversa muito interessante c/um grupo de mulheres inteligentes e antenadas em S. Paulo". O termo "Amigos" foi repetido 13 vezes: "Queria agradecer a presença de todos os amigos, inclusive os governadores @eduardocampos40 e Jaques Wagner, na inauguração do comitê Bsb." A sigla PT foi mencionada 11 vezes: "Ao lado do presidente Lula, dos companheiros do PT e dos partidos aliados, foi muito bom dizer e ouvir das companheiras: mulher pode!!!"

Dilma Rousseff foi a candidata que teve seu nome mais citado e apareceu por mais tempo na lista do Trending Topics. O termo "Dilma” (Rousseff) é o maior destaque, na sétima colocação: ele figurou no ranking mundial por 7 dias, 18 horas e 58 minutos, totalizando 84 ocorrências. ${ }^{14}$

\subsection{Marina Silva (@silva_marina)}

Marina Silva começou a utilizar o Twitter no dia 15 de janeiro de 2010. Marina foi a candidata que teve o maior crescimento de seguidores no período estudado. No dia 6 de julho, a candidata tinha 85.590 seguidores, passou para 113.988 no dia 31 de julho e chegou, em 31 de agosto, a 172.834 seguidores. No final do período estudado, Marina Silva contava com 339.821 seguidores. O crescimento foi de 254.231 novos seguidores (297\%), uma média de 2.118 seguidores por dia.

Gráfico 13 - Evolução dos seguidores de Marina Silva (6 de julho-2 de novembro)

\section{Evolução dos seguidores da candidata Marina Silva}

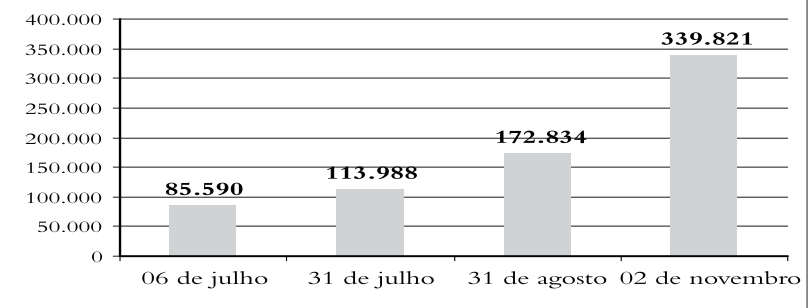

Fonte: Elaborado pelo autor, 2010

Marina postou as mensagens com maior frequência das 8 da manhã ao meio-dia. No quesito mensagens, Marina foi a candidata que mais tweets mandou: postou 615 mensagens em 57 dias (de 6 de julho até 31 de agosto), uma média de 10,7 mensagens por dia. Marina deu RT em 17,08\% das suas mensagens.

Segundo a própria candidata Marina Silva, o Twitter não é para fazer propaganda, mas para conversar/escutar: "O Twitter, para mim, não é uma ferra- 
menta de propaganda. Uso para conversar, principalmente para escutar." As postagens das mensagens no Twitter são feitas diretamente pelos autores, no caso de Serra e de Marina Silva. Já no caso da candidata Dilma algumas mensagens são emitidas por sua equipe.

As palavras mais citadas por Marina foram: "Migre", com 580 citações (é quando a candidata está indicando uma página a ser seguida); "Marina", escrita 134 vezes; "Programa" teve 50 menções; "Agenda" apresentou 25 registros; "Ambiente", com 22 citações; "Coletiva", 28 vezes mencionada; a palavra "Entrevista" foi dita 81 vezes; "Estou" foi mencionada 75 vezes, e "Hoje", 111 vezes. Percebe-se que Marina utilizou mais o Twitter para a divulgação de sua agenda.

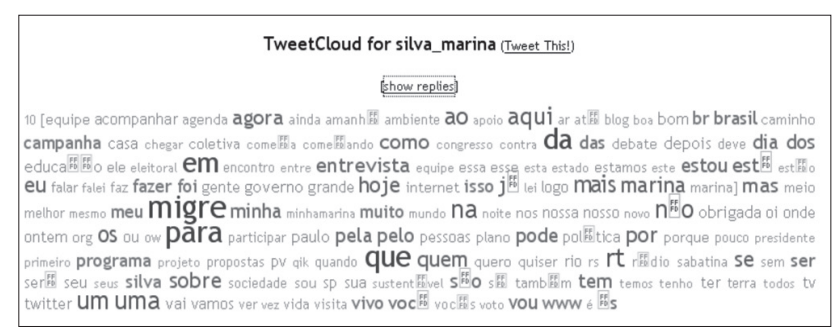

Figura 4 - Palavras mais citadas por Marina Silva no Twitter Fonte: Tweetstats. 2010. Disponível em: <http://tweetstats.com/graphs/ silva_marina\#tcloud>. Acesso em: 3 Nov. 2010.

\section{O segundo turno}

Já no segundo turno, os candidatos à presidência intensificaram as postagens no Twitter, com o aumento do número de seguidores dos dois candidatos que disputaram o segundo turno das eleições 2010, Dilma Rousseff (PT) e José Serra (PSDB). Outro aspecto a ser analisado nesta seção foram as manifes- tações de xenofobia de internautas que, logo após a conclamação dos resultados, postaram mensagem racistas e preconceituosas no Twitter.

O período analisado nesta seção inicia no dia 3 de outubro (primeiro dia do segundo turno das eleições), até o dia 2 de novembro de 2010 (dois dias após o termino das eleições).

As notícias sobre os candidatos Dilma Rousseff e José Serra no segundo turno nas mídias on-line (jornais e revistas) somaram mais de 10 mil notícias em todo o país: a candidata Dilma Rousseff foi mais citada do que o candidato do PSDB: foram 7.468 notícias para Dilma e 3.157 notícias para Serra (Gráfico 14).

Da mesma forma, a incidência de notícias sobre os dois candidatos nos portais da web e na televisão foram consideravelmente expressivos, alcançando mais de 5.700 inserções: Dilma alcançou 4.315, contra 1.389 de Serra (Gráfico 15).

A visibilidade dos dois candidatos no Twitter nos últimos dois meses do período eleitoral (do dia 29 de setembro até o dia 21 de novembro de 2010) manteve os mesmos índices (Gráfico 16).

Logo após os números confirmarem a vitória da candidata Dilma Rousseff na disputa presidencial, viu-se uma batalha on-line no Twitter. As discussões e críticas extrapolaram de ambos os lados, tanto dos derrotados (partidários do candidato Serra) quanto dos vencedores (apoiadores da candidata Dilma). Iniciou-se uma avalanche de postagens com mensagens de cunho bairrista, preconceituoso e racista, principalmente dos internautas que apoiavam o candidato derrotado. Eles acusavam uma determinada região do país, o Nordeste, por ser "responsável" pela vitória da candidata Dilma. Uma das mensagens dizia: "O Brasil podia ser dividido entre atrasados e retardados do Norte e Nordeste, e nós que queremos evoluir, eles

Gráfico 14 - Visibilidade dos candidatos Dilma Rousseff e José Serra na imprensa on-line (mês de outubro de 2010)

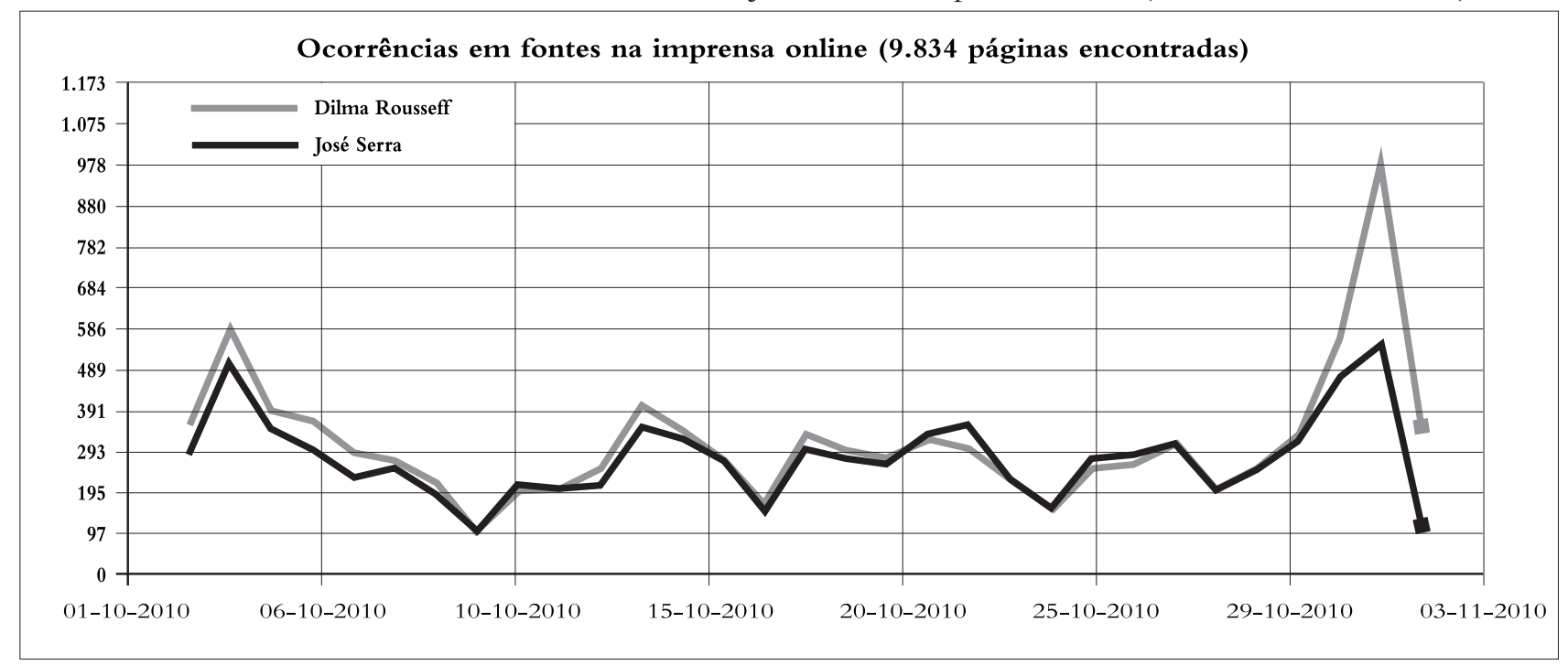

Fonte: Observatório das Eleições. 2010. Disponível em: <http://observatorio.inweb.org.br/eleicoes2010/personalidades/fontes/dilma-rousseff>. Acesso em: 29 set. 2010. 
Gráfico 15 - Visibilidade dos candidatos Dilma Rousseff e José Serra nos portais da web e na televisão (mês de outubro de 2010)

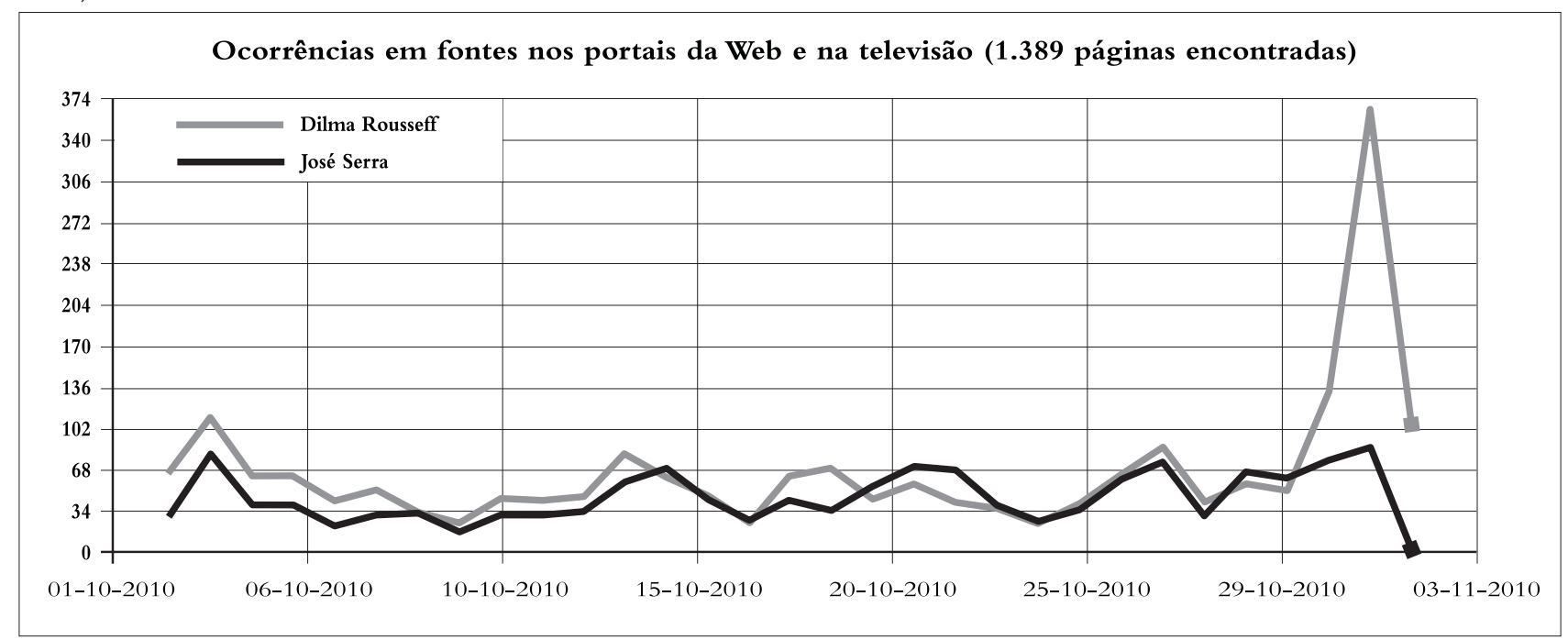

Fonte: Observatório das Eleições. 2010. Disponível em: <http://observatorio.inweb.org.br/eleicoes2010/personalidades/fontes/jose-serra>. Acesso em: 29 set. 2010.

Gráfico 16 - Visibilidade de Dilma e Serra no Twitter

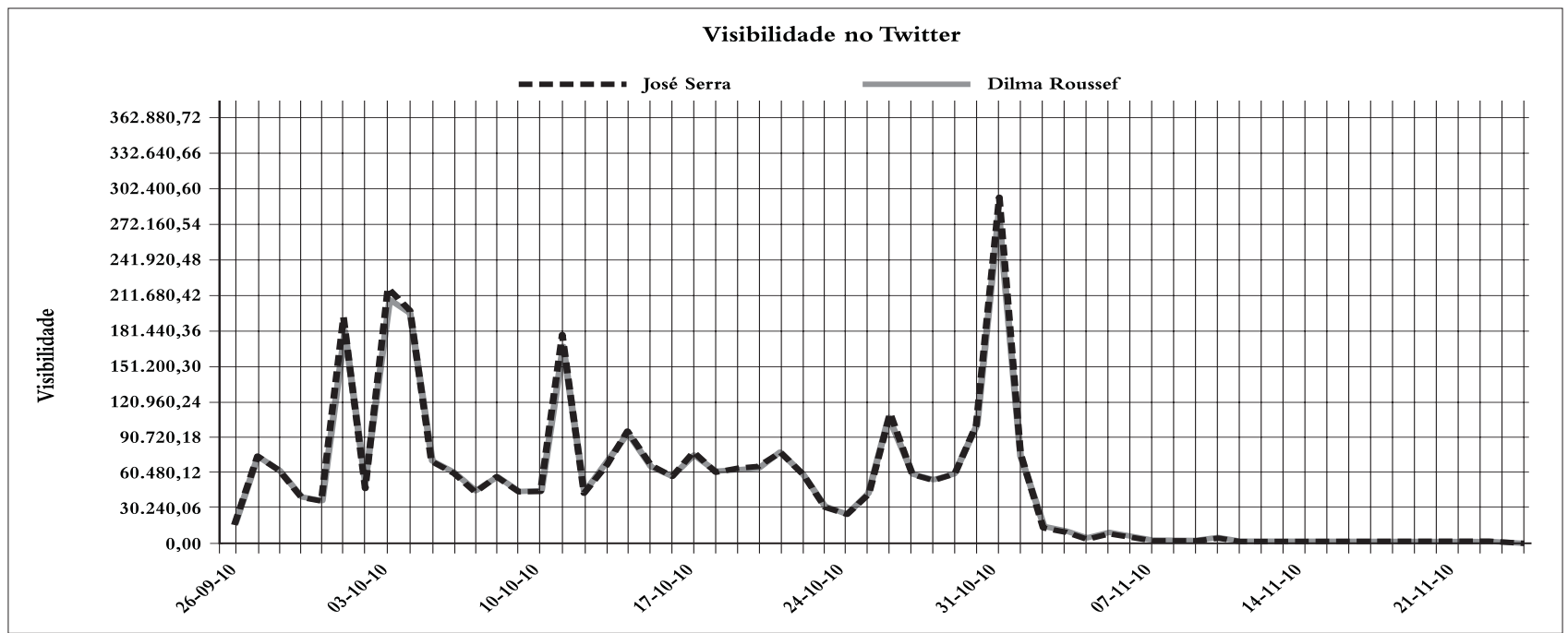

Fonte: Observatório das Eleições. 2010. Disponível em: <http://observatorio.inweb.org.br/eleicoes2010/personalidades/jose-serra>. Acesso em: 29 Set. 2010.

ficaram com a Dilma." O caso mais sério foi o da estudante do curso de Direito de São Paulo Mayara Petruso: "Nordestino não é gente, faça um favor a São Paulo, mate um nordestino afogado." Este comentário rendeu à internauta uma notícia-crime impetrada pela OAB-PE, configurando a mensagem como crime de racismo tipificado no caput e parágrafo $2^{\circ}$ do Artigo da Lei no 7.716, de 5 de janeiro de 1989.

\section{Considerações finais}

Com o término do segundo turno e com os votos computados, os coordenadores das redes sociais dos três candidatos avaliados, Dilma Rousseff (PT), José Serra (PSDB) e Marina Silva (PV), foram unânimes em afirmar que a utilização da internet teve grande importância nessas eleições, fazendo com que ela fosse, inclusive, decidida no segundo turno: "É possível afirmar que, sem a utilização da internet, certamente não haveria segundo turno", afirmou o jornalista Caio Túlio Costa, estrategista da campanha de Marina Silva nas mídias sociais. Notou-se também 
a expressiva mobilização dos eleitores da candidata Marina Silva (PV) pela web, pois fez com que a candidata pudesse alcançar mais de 19 milhões (19,33\%) dos votos válidos no primeiro turno (Costa, 2011).

O coordenador da campanha da candidata Dilma Rousseff, Marcelo Branco, também entende que a internet foi fundamental para a realização do segundo turno. Contrariando as expectativas da mídia tradicional ( $\mathrm{TV}$, rádio e jornal) de que a internet não seria importante nessas eleições, o que se viu foi o contrário: os presidenciáveis utilizaram, e muito, a internet, com os blogs, os sites oficiais e, principalmente, as redes sociais, tais como o Facebook, o Orkut, o YouTube e o Twitter.

Neste sentido, esta análise procurou apresentar, inicialmente, uma breve evolução histórica da internet no mundo e sua propagação no Brasil (evolução do número de usuários). Logo após, discutiu-se se o Twitter é uma ferramenta geradora de capital social, nos sentido de que há elementos de reciprocidade e participação política fomentando o espírito cívico dos usuários e, posteriormente, a importância do Twitter dentro das redes sociais, bem como a utilização do Twitter na campanha eleitoral 2010 no Brasil. Fez-se uma análise do emprego do Twitter pelos três principais candidatos à Presidência da República do Brasil, José Serra, Dilma Rousseff e Marina Silva, principalmente na evolução dos seguidores, postagem das mensagens, exposição e citação no Twitter, além das palavras mais citadas por eles. Como método, a pesquisa analisou as contas dos referidos candidatos desde o dia 3 de julho até o dia 2 de novembro de 2010 (120 dias). Utilizaram-se sites que mensuram as contas do Twitter com o objetivo de demonstrar a sua evolução (o <http://tweetstats.com> e o <http://twittercounter.com/ $>$, respectivamente). Buscou-se, igualmente, a opinião de alguns especialistas em redes sociais no intuito de perceber a sua utilização e a relação com a política.

A partir dos resultados das eleições 2010, algumas conclusões foram possíveis de serem apontadas.

A eleição de 2010 foi a primeira a utilizar o Twitter de forma tão intensa. Além do rádio e da TV, a internet aparece agora como um meio significativo de comunicação do meio político (relação entre candidatos e eleitores).

Questionava-se no início deste trabalho se a utilização do Twitter pelos candidatos seria um mecanismo de debate (formação de opinião) que poderia traduzir-se em votos (um palanque eletrônico), ou o Twitter seria apenas um mecanismo de propagação de ideias que não se traduziria em votos. $O$ que se percebeu foi que, ao usar uma ferramenta para disponibilizar informações, como no caso da utilização do Twitter, evidencia-se o caráter social do sistema, vindo a mobilizar diferentes tipos de capital social, resultando em novas formas de estabelecer ou manter laços sociais em um ambiente de rede social, em que os usuários estão conectados entre si e interagem através das mensagens que trocam uns com os outros. Nessas interações, percebe-se a cooperação e a reciprocidade dos indivíduos formando laços sociais. Assim, pode-se dizer que "a comunicação em massa tem papel central para a democracia contemporânea" (Gomes e Maia, 2008, p. 115).

Pois bem, uma análise preliminar dá conta de que a utilização dos mecanismos do Twitter mostrou-se um meio bastante eficaz para os candidatos se aproximarem de seus eleitores, bem como um instrumento positivo para o eleitorado identificar as estratégias políticas dos candidatos. Até agora, se pode perceber que é mais fácil um candidato a um cargo político perder votos se não estiver nas redes sociais do que ganhar voto estando nelas. A utilização do Twitter é uma prestação de serviço obrigatória dos candidatos numa relação direta com o eleitor. A utilização do Twitter por um candidato não garante necessariamente a vitória em um pleito, pois os números de usuários do Twitter, bem como dos seguidores dos principais candidatos, ainda são pouco expressivos para definir uma eleição. No entanto, notou-se que utilizar o instrumento ajudou, e muito, não apenas na visibilidade do candidato, mas na mobilização dos eleitores em defender seus respectivos candidatos. 


\section{Referências}

ABREU, Karen Cristina Kraemer. História e usos da internet. Disponível em: http://www.bocc.ubi.pt/pag/ abreu-karen-historia-e-usos-da-internet.pdf. Acesso em: maio 2012.

ALDÉ, Alessandra. A construção da política: democracia, cidadania e meios de comunicação de massa. Rio de Janeiro: Editora FGV, 2004.

BARROS, C. T. G. Internet como esfera pública? Análise de usos e repercussões reais das discussões virtuais. In: IV CONGRESSO LATINO AMERICANO DE OPINIÃO PÚBLICA DA WAPOR, de 4 a 6 de maio de 2011. Anais: Portal de Opinião Pública (www.opiniaopublica.ufmg. br).

COSTA, Caio Túlio. O papel da internet na conquista dos votos de Marina Silva. Disponível em: http://ecorelease.files. wordpress.com/2011/04/paper-marina-silva-14042011. pdf. Acesso em: maio 2012.

GOMES, Wilson; MAIA, Rousiley. Comunicação $e$ democracia: problemas e perspectivas. São Paulo: Paulus, 2008.

HANIFAN, Lyda. The rural school community center. Annals of the American Academy of Political and Social Science, Philadelphia, v. 67, n 1, p. 130-138, sep. 1916.

IBGE. 2005. IBGE contou 32,1 milhões de usuários da Internet no país. Disponível em: <http://www.ibge.gov. $\mathrm{br} /$ home/presidencia/noticias/noticia_visualiza.php?id_ noticia $=846>$. Acesso em: ago. 2010 .

IDG Now, Nielsen, Terra, Webinsider. Politicos brasileiros $e$ as redes sociais. 2009. Disponível em: <http://www. slideshare.net/mapadigital/politicos-brasileiros-e-asredes-sociais? $\mathrm{src}=$ related_normal\&rel $=1646118>$. Acesso em: 28 set. 2010.

JACOBS, Jane. The death and life of great American cities. New York: Random House, 1961.

JORNAL ESTADÃO ON LINE. Brasil também é o $5^{\circ}$ maior mercado para internet e celular no mundo. Disponível em: $<$ http://www.estadao.com.br/noticias/economia,brasile-o-5-maior-mercado-para-celular-e-internet-nomundo,454912,0.htm >. Acesso em: ago. 2010.

JORNAL FOLHA DE SÃO PAULO. Facebook e Twitter crescem nas redes sociais; Orkut continua líder. Disponível em: <http://www1.folha.uol.com.br/folha/informatica/ ult124u726772.shtml>. Acesso em: ago. 2010.

JORNAL FOLHA DE SÃO PAULO. Números apresentados até a data da pesquisa: 26 de julho de 2010. Disponível em: <http://www1.folha.uol.com.br/folha/informatica/ ult124u683533.shtml>.

JORNAL O GLOBO ON-LINE. O que é: rede social. Disponível em: <http://g1.globo.com/Noticias/0, MUL394839-15524,00.html>. Acesso em: ago. 2010.

LEMOS, A. Nova esfera conversacional. In: MARQUES, Ângela; COSTA, Caio Túlio; KÜNSCH, Dima et. al. (Orgs.). Esfera pública, redes e jornalismo. Rio de Janeiro:
E-Papers, 2009. p. 13-24

LÉVY, P. Cibercultura. 2. ed. São Paulo: Editora 34, 2000. LOPES, N. F. A. Política na Rede: papel das redes sociais da internet na campanha eleitoral para a Presidência da República no Brasil em 2010. In: CONGRESSO LATINO AMERICANO DE OPINIÃO PÚBLICA -WAPOR, 4, 2011, Belo Horizonte, p. 1-47, 2011.

MAGAlHÃES, Vera. Políticos migram ao Twitter, mas poucos o usam direito. Folha de São Paulo. Disponível em: <http://www1.folha.uol.com.br/folha/informatica/ ult124u683533.shtml>. Acesso em: jul. 2010.

OBSERVATÓRIO IN WEB. Observatório das eleições 2010 desenvolvido pelo InWeb - Instituto Nacional de Ciência e Tecnologia para a Web. Disponível em: <http://www. observatorio.inweb.org.br/eleicoes2010/destaques/>

ORGANIZAÇÃO DAS NAÇÕES UNIDAS. Número de internautas no Brasil. Disponível em: http://www.estadao. com.br/noticias/economia,brasil-e-o-5-maior-mercadopara-celular-e-internet-no-mundo,454912,0.htm. Acesso em: out. 2010 .

PENTEADO, C. Informação e contra-afirmação: o papel dos blogs no debate político das eleições presidenciais de 2010. In: CONGRESSO LATINO AMERICANO DE OPINIÃO PÚBLICA -- WAPOR, 4. 2011, Belo Horizonte. Anais do IV Congresso Latino Americano de Opinião Pública. Belo Horizonte: WAPOR, 2011. p. 1-27.

Por que o Twitter é tão popular no Brasil? Disponível em: http://www.ihu.unisinos.br/index.php?option=com_no ticias $\&$ Itemid $=18 \&$ task $=$ detalhe $\& \mathrm{id}=37771$. Acesso em: nov. 2010.

PUTNAM, R. Comunidade e democracia: a experiência da Itália moderna. Rio de Janeiro: Editora FGV, 2002.

RAMALDES, D. Twitosfera: a expansão da ágora digital e seus efeitos no universo político. 2009. Disponível em: $<$ http://jpcelular.files.wordpress.com/2009/11/artigo_ compolitica_2009.pdf>. Acesso em: 6 nov. 2010.

REVISTA SUPERINTERESSANTE. República do Twitter. Disponível em: <http://super.abril.com.br/ alimentacao/republica-twitter-544297.shtml>. Acesso em: ago. 2010.

ROTHBERG, D. A sociedade em rede e suas razões para o voto: impactos da internet sobre a dimensão sociopolítica. In: CONGRESSO LATINO AMERICANO DE OPINIÃO PÚBLICA - WAPOR, 4., 2011, Belo Horizonte. Anais do IV Congresso Latino Americano de Opinião Pública, p. $1-29$.

SITE DE BUSCA DO TWITTER. Disponível em: <http://tweetstats.com>. Acesso em: dez. 2010.

SITE DE BUSCA DO TWITTER. Disponível em: <http://twittercounter.com/> Acesso em: dez. 2010.

SBARAI, Rafael. A barulhenta invasão brasileira no Twitter. Disponível em: http://veja.abril.com.br/noticia/vida- 
digital/a-barulhenta-invasao-brasileira-no-twitter?utm source $=$ twitterfeed\&utm_medium $=$ twitter. Acesso em: abr. 2010.

TEC MUNDO. É oficial: Facebook é a rede social mais utilizada no Brasil. Disponível em: http://www. tecmundo.com.br/facebook/19481-e-oficial-facebook-ea-rede-social-mais-utilizada-no-brasil.htm. Acesso em: maio 2012.

TEIXEIRA, T. Web 2.0, cidadãos e política: riscos e oportunidades para a democracia. In: Anais do IV Congresso Latino Americano de Opinião Pública - WAPOR 4, Belo Horizonte, 2011, p. 1-22.

TO BE GUARANY. Estatísticas, dados e projeções atuais sobre a Internet no Brasil. Disponível em: http://tobeguarany. com/internet_no_brasil.php. Acesso em: maio 2012.
TOCQUEVILle, Alexis de. A democracia na América. 3. ed. Belo Horizonte: Itatiaia, 1969.

TWITTER CENTRAL. Censo de usuários de Twitter no Brasil. Disponível em: <http://www.twittercentral.com. br/censobr/>. Acesso em: ago. 2010.

UNIVERSO ON-LINE. Redes sociais revelam orgulho $e$ preconceito em relação ao Nordeste. Disponível em: http:// eleicoes.uol.com.br/2010/ultimas-noticias/2010/11/01/ redes-sociais-revelam-orgulho-e-preconceito-emrelacao-ao-nordeste.jhtm. Acesso em: nov. 2010.

Usuários de Internet no Brasil. Disponível em: <http://www. teleco.com.br/internet.asp>. Acesso em: ago. 2010.

XENOFOBIA NÃO. Diga não à xenofobia. Disponível em: $<$ http://xenofobianao.tumblr.com/>. Acesso em: nov. 2010 .

\title{
On-line politics: the use of Twitter as a tool of social capital in the 2010 presidential elections
}

\begin{abstract}
This study was guided by the hypothesis that the use of social networks (Twitter) in Brazil's presidential elections, in 2010, was a favorable factor to the production of social capital and civility. Accordingly, this article presents a study on the use of Twitter by the three major presidential candidates for that year: José Serra (PSDB), Dilma Rousseff (PT) and Marina Silva (PV). The analysis followed, more specifically, the candidates' Twitter accounts for 120 days (from July $6^{\text {th }}$ to November $2^{\text {nd }}, 2010$ ). First time used in an electoral process in Brazil, the Twitter was employed mainly for the dissemination of agendas, and also to approach the voters to their candidates, catalyzing civic participation. This study showed that Twitter contributed to the democratic debate and to the candidates' electorate's mobilization, mainly Marina Silva's voters, fact that took the election to be decided in a second round.
\end{abstract}

Key words: election campaign 2010, social capital, civic participation, Twitter.

\section{Política on-line: la utilización de Twitter como instrumento de capital social en las elecciones presidenciales de 2010}

\section{Resumen}

Este estúdio está guiado por la hipótesis de que el uso de las redes sociales (Twitter) en las elecciones presidenciales de 2010 en Brasil fue un factor favorable para la producción de capital social y educación cívica. En este sentido, este artículo presenta un estúdio sobre el uso de Twitter por los tres principales candidatos a la presidencia de Brasil em las elecciones generales en el 2010: José Serra (PSDB), Dilma Rousseff (PT) y Marina Silva (PV). Los presentes análisis se siguieron, más concretamente, la cuenta de Twitter de los candidatos durante 120 días (desde Julio 6 a noviembre 2, 2010). Utilizado por primera vez en un proceso electoral en Brasil, el Twitter fue usado principalmente para la divulgación de las agendas, para acercar a los votantes de sus candidatos y también catalizar la participación ciudadana. Este trabajo mostró que el Twitter contibuyó a un debate democrático y la movilización del electorado, de los candidatos, sobretodo a los votantes de la candidata Marina Silva, lo que condució la elección a ser dicidida en una segunda ronda.

Palabras-clave: campaña electoral 2010, participación social y ciudadana, Twitter.

Data de recebimento do artigo: 10/11/2011

Data de aprovação do artigo: 21/02/2012 